\title{
HUMAN PAPILLOMAVIRUS GENOTYPE SPECTRUM IN STUDIED GROUP OF MONTENEGRIN WOMEN
}

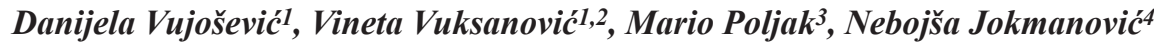

Center for Medical Microbiology, Institute of Public Health, Podgorica, Montenegro ${ }^{1}$; Medical Faculty, University of Montenegro, Podgorica, Montenegro ${ }^{2}$; Institute of Microbiology and Immunology, Faculty of Medicine, Ljubljana, Slovenia $^{3}$; Clinic for Gynecology and Obstetrics, Clinical Center of Montenegro, Podgorica, Montenegro 4

\begin{abstract}
Summary: The risk of high-grade lesions and carcinoma is known to correlate with specific high-risk HPV genotypes. The distribution of HPV types varies between countries and little is known about HPV distribution in our country. Therefore, the purpose of this study was to determine the range and frequency of HPV genotypes in studied group of women in Montenegro. HPV genotypes were determined using the method of enzyme restriction of PCR products amplified with group-specific primers MY09/MY11 and restricted with seven different restriction endonucleases. Out of the total number of women HPV infection was found in 1/5 of participants (20\%). Genotyping performed in HPV DNA positive women shows that the HPV genotype 16 is dominant and present in more than $1 / 3$ of the participants (36.8\%). The second most frequent HPV infection is with HPV genotype 58 and it is found in 10.5\% of participants. HPV 31 and HPV 6 infections are present in $7.9 \%$ of women, while infections with other genotypes were demonstrated individually by $2.6 \%$. Multiple HPV infection was demonstrated in $18.4 \%$ and they are dominant in younger women (aged 25 to 30 years).
\end{abstract}

Key words: HPV genotype; PCR; RFLP; Multiple HPV infection

\section{Introduction}

Infection with high-risk genotypes of human papillomaviruses (HPV) is the main etiological agent of cervical cancer, the second most common form of cancer in women worldwide $(8,17)$. More than 100 different HPV genotypes have been identified (and their number is still growing), out of which approximately 45 were detected in anogenital region $(4,16)$. Among these, potentially highrisk HPV genotypes, 16, 18, 31, 33, 35, 39, 45, 51, 52, 56, 58,59 (and probably high-risk types 26, 53, 66, 68, 73, and 82 ), are defined based on their prevalence in cervical intraepithelial neoplasia (CIN) lesions and cervical cancers $(5,6)$. The results of recent studies have shown that the prevalence of high-risk HPV genotypes increases with increasing degree of $\mathrm{CIN}$ and that the prevalence of infection with HPV in women with invasive form of cervical cancer is $99.7 \%(2,14)$.

The distribution of HPV types varies between countries (5) and little is known about HPV distribution in our country. The main objective of this study was to determine the range and frequency of HPV genotypes in studied women in Montenegro. Modern techniques of molecular virology were used, which is the first and only study of its kind in Montenegro by now days.

\section{Material and Methods}

A total of 189 cervical specimens obtained from the same number of women were involved in the study. Cervical smears were taken from women during a routine gynecological examination at the Clinical Center in Podgorica. Sampling was done using a commercial diagnostic kit HC II (Digene Specimen Collection Kit, Silver Spring, Maryland, USA). Diagnostic was performed with PCR method by detection of DNA HPV in cervical materials at the Laboratory for Molecular Microbiology and Diagnostics of AIDS, the Institute of Microbiology and Immunology, Faculty of Medicine in Ljubljana. DNA from cervical smears samples was isolated by a procedure previously developed in that laboratory (10).

For HPV DNA amplification two group-specific primers MY09 and MY11 were used. Primers MY09 and MY11 allow amplification of $450 \mathrm{bp}$ large, very conservative part of the L1 gene. More than 50 different HPV genotypes in a one PCR reaction can be covered by using these primers. After completion of PCR, specificity of PCR products (amplicons) was determined by gel-electrophoresis by previously described procedure (12).

For to determination HPV genotype, restriction fragment length polymorphism (RFLP) method was performed by using seven different restriction endonucleases: $B a m H I$, DdeI, HaeIII, DNA HinfI digest, PstI, RsaI, and Sau3AI 
(Gibco-BRL, Bethesda, USA). Forty-four different restriction patterns of MY09/MY11 PCR products have been described. Individual sample restriction is characteristic for the certain HPV genotype. Patterns of enzyme restriction of PCR products were compared to predefined standard patterns of restriction and in this way defined genotype $(1,12)$.

\section{Results}

Out of 189 women included in the survey about $4 / 5$ women $(79 \%)$ belong to a group of women from 20 to 45 years of age, which indicates that these are participants in full sexual maturity and sexual activity. Average age of participants was 38 years. The youngest woman was 23 and the oldest 68 years old.

HPV infection was found in $1 / 5$ of our participants $(20 \%, 38 / 189)$. Genotyping performed in 38 HPV DNA positive women showed that the HPV genotype 16 was present in $36.8 \%$; HPV 58 infection was at the second place and it is found in $10.5 \%$; HPV 31 and HPV 6 infections were present in $7.9 \%$ of HPV positive women, while infections with other genotypes were demonstrated individually by $2.6 \%$ (Table 1 ).

At the end of the study a total of 16 different HPV genotypes in $38 \mathrm{HPV}$ positive women were detected. HPV infection with one genotype was dominant (Table 1). HPV single infection is present in $4 / 5$ patients $(81.6 \%, 31 / 38)$. Infection caused by two different HPV genotypes was found in $15.8 \%(6 / 38)$ of women, while in one woman $(2.6 \%)$ infection caused by three different HPV genotypes was found. Multiple infections were demonstrated in seven (18.4\%) HPV infected women (Table 1).

Tab. 1: Distribution of HPV genotypes in 38 HPV infected women in Montenegro

\begin{tabular}{|l|c|c|}
\hline $\begin{array}{c}\text { HPV } \\
\text { genotype }\end{array}$ & $\begin{array}{c}\text { No. } \\
\text { of women }\end{array}$ & $\begin{array}{c}\text { Percent } \\
\text { of women (\%) }\end{array}$ \\
\hline 6 & 3 & 7.9 \\
\hline 16 & 14 & 36.8 \\
\hline 31 & 3 & 7.9 \\
\hline 33 & 1 & 2.6 \\
\hline 51 & 1 & 2.6 \\
\hline 52 & 1 & 2.6 \\
\hline 54 & 1 & 2.6 \\
\hline 58 & 4 & 10.5 \\
\hline 61 & 1 & 2.6 \\
\hline 66 & 1 & 2.6 \\
\hline MM7 & 1 & 2.6 \\
\hline $6+\mathrm{M} 109+58$ & 1 & 2.6 \\
\hline
\end{tabular}

\begin{tabular}{|l|c|c|}
\hline $16+6$ & 1 & 2.6 \\
\hline $16+52$ & 1 & 2.6 \\
\hline $16+\mathrm{CP} 8304$ & 1 & 2.6 \\
\hline $18+53$ & 1 & 2.6 \\
\hline $26+\mathrm{X}^{*}$ & 1 & 2.6 \\
\hline $58+52$ & 1 & 2.6 \\
\hline Total & 38 & 100 \\
\hline
\end{tabular}

*undefined HPV genotype

Analyzing 16 detected HPV genotypes, in $4 / 5$ patients $(81.6 \%, 31 / 38)$ the presence of high-risk HPV genotypes was confirmed. In two women (5.2\%) the presence of probably high-risk genotypes was found, whereas the low-risk HPV genotypes were present in 5 women (13.2\%).In our study out of 38 HPV DNA positive participants the infection was most common in women aged $20-30$ years, even $65.8 \%(25 / 38)$, while the remaining $13 / 38(34.2 \%)$ was detected in women aged 40-50 years. Multiple infections were found in younger women, aged 25 to 30 years.

\section{Discussion}

HPV infection is associated with increased risk of developing cervical cancer (17). In this regard, accurate detection of HPV infection is clinically important and requires a reliable diagnostic method. We can say that the sensitive detection of HPV and accurate genotyping are crucial. Early detection of HPV, followed by treatment of cervical dysplasia, can significantly reduce the risk of developing cervical cancer (15).

In our study infection with 16 different HPV genotypes was found. The most common HPV genotypes were HPV $16(36.8 \%)$ and HPV 58 (10.5\%). In other words half of the studied HPV positive women have infection with these two genotypes. These results suggest that it is necessary to do a broader study of HPV infection and genotyping, especially since there are deviations from the common HPV genotypes. The establishment for further observation of our population of women is the fact that meta-analysis conducted based on studies published from 1995 to 2009 in $1,016,719$ women, showed that five types of $\operatorname{HPV}(16,18$, 31,52 , and 58) are most frequent genotypes (3). The study included only those researches based on PCR technology.

In our study we find out that HPV infection are more common in younger women $(68.5 \%$ in women ages 20 to 30 years). Also, it was found that mixed HPV infection, with more than one HPV genotype is dominant in younger women and with at least one high-risk or probably highrisk HPV genotype. These findings correlate with HPV prevalence among young women worldwide (18). Castel P et al concluded that HPV16 is more strongly associated with cervical precancer diagnosed in younger women 
(vs. older women). HPV18 infections were linked to precancerous lesions that were missed by cytology (19). Considering that young women with persistent high-risk HPV infection, specially types 16 and 18 , are more susceptible for developing a precancerous cervical leasions $(20,21)$.

\section{Conclusions}

In our study, we found the presence of different HPV genotypes, total 16 . In our country, the same as in the world, infection with genotype HPV 16 is most common, followed by infection with HPV 58, HPV 31 and HPV 6.

\section{References}

1. Bernard HU, Chan SY, Manos MM. Identification and assessment of know an novel human papilomaviruses by polymerase chain reaction amplification, restriction fragment lenth polymorphism, nucleotide sequence, and phylogenetic lgorithms. J Infect Dis 1994; 170: 1077-85.

2. Bosch FX, Manos MM, Munoz, et al. Prevalence of Human papillomaviruses in cervical cancer: a worldwide perspective. J Natl Cancer Inst 1995; 87: 796-802 3. Bruni L, Diaz M, Castellsagué X, Ferrer E, Bosch FX, de Sanjose S. Cervica Human Papillomavirus Prevalence in 5 Continents: Meta-Analysis of 1 Million Women with Normal Cytological Findings. J Infect Dis 2010; 202: 1789-99.

4. De Villiers EM, Fauquet C, Broker TR, Bernard HU, zur Hausen H. Classification of papillomaviruses. Virology 2004; 324: 17-27.

5. Li N, Franceschi S, Howell-Jones R, Snijders PJ, Clifford GM. Human papillomavirus type distribution in 30,848 invasive cervical cancers worldwide: Variation by geographical region, histological type and year of publication. Int J Cancer 2011; 128: 927-35.

6. Muñoz N, Bosch FX, de Sanjose S, et al. Epidemiologic classification of human papillomavirus types associated with cervical cancer. N Engl J. Med 2003; 348(6): 518-27.
7. Munoz N, Castellsaque X, Gonzales AB, Gissman L. HPV in the etiology of human cancer. Vaccin 2006; 24: S3: 1-10.

8. Parkin DM, Pisani P, Ferlay J. Estimates of the worldwide incidence od eighteen major cancers in 1985. Int J Cancer 1993; 54: 606.

9. Poljak M, Avšić-Županc T, Seme K. Verižna reakcija s polmerazo - nova raziskovalna in diagnostična metoda v virologiji. Med Razgl 1994; 33: 379-400.

10. Poljak M, Brenčić A, Seme K, et al. Comparative evaluation of the first and second generation Digene Hybrid Capture assays for detection of human papillomaviruses associated with high or intermediate risk for cervical cancer. J Clin Microbiol 1999; 37: 796-7.

11. Poljak M, Seme K, Koren S. The polymerase chain reaction: a critical review of its uses and limitations in diagnostic microbiology. Period Biol 1996: 98: 183-90.

12. Poljak M, Seme K, Gale N. Detection of human papillomaviruses in tissue specimens. Adv Anatomic Pathol 1998; 5: 216-34.

13. Smith JS, Lindsay L, Hoots B, et al. Human papillomavirus type distribution in invasive cervical cancer and high-grade cervical lesions: a meta-analyses update Int J Cancer 2007; 121: 621-32.

14. Stoler MH. Human papillomaviruses and cervical neoplasia: a model for carcinogenesis. Int J Gynecol Pathol 2000; 19: 16-28.

15. Wright Jr TC, Massad S, Dunton CJ, et al. 2006 consensus guidelines for the management of women with abnormal cervical screening tests. J Low Genit Tract Dis 2007; 11: 201-22.

16. zur Hausen H. Viruses in human tumors - reminiscences and perspectives. Ady Cancer Res 1996; 68: 1-22.

17. zur Hausen H. Papillomaviruses in the causation of human cancers - a brief historical account. Virology 2009; 384: 260-5.

18. Winer RL, Lee SK, Hughes JP, Adam DE, Kiviat NB, Koutsky LA, et al.Genital human papillomav irus infection: incidence and risk factors in acohort of female university students. Am J Epidemiol 2003; 157: 218-26.

19. Philip E, Castle RS, LaMere BJ, et al. Human Papillomavirus (HPV) Genotypes in Women with Cervical Precancer and Cancer at Kaiser Permanente Northern California. Cancer Epidemiol Biomarkers Prev 2011; 20: 946-53.

20. de Sanjose S, Quint WG, Alemany L, Geraets DT, Klaustermeier JE, Lloveras B, et al. Human papillomavirus genotype attribution in invasive cervical cancer: a retrospective cross-sectional worldwide study. Lancet Oncol 2010; 11: 1048-56.

21. Khan MJ, Castle PE, Lorincz AT, Wacholder S, Sherman M, Scott DR, et al. The elevated 10 -year risk of cervical precancer and cancer in women with human papillomavirus (HPV) type 16 or 18 and the possible utility of type-specific HPV testing in clinical practic e. J Natl Cancer Inst 2005; 97: 1072-9.

Received: 07/02/2011

Accepted in revised form: 05/09/2012

\section{Corresponding author:}

Danijela Vujošević, PhD, Center for Medical Microbiology, Institute of Public Health, Džona Džeksona bb, 81000 , Podgorica, Montenegro; e-mail: danijela.vujosevic@ijzcg.me 